\title{
Names of Jesus in Mark's story
}

\author{
Yolanda Dreyer \\ Department of Practical Theology \\ University of Pretoria \\ PRETORIA \\ E-mail: ydreyer@postino.up.ac.za
}

\begin{abstract}
Names of Jesus in Mark's story

Mark as narrator treats the concept "Messiah" as a description of Jesus' identity, but this alone does not suffice: the title "Son of God" is added in order to describe Jesus' identity more fully. According to Mark it is not the Twelve but some of the other followers who praise Jesus with the title of the "Blessed One who comes in the name of the Kyrios". "Messiah" is the title the disciples give to Jesus, but the "narrated Jesus" subordinates the title "Messiah" to the title "Kyrios". The aim of this article is to focus on Mark as narrative. The article argues that all events are presented from one perspective, that is the perspective of Jesus. This perspective is narrated by using names of Jesus. The article focuses on these names as used in the Gospel of Mark.
\end{abstract}

\section{Introduction}

Narrative criticism discloses how characters are portrayed in a narrative. Some characters merely play a "decorative" role and are not important for the development of the plot. They can fulfil the function of, for instance, creating the norms for judging the main character. The narrator's intention is revealed in the way in which the characters relate to one another. This perspective can be seen in the emotions, observations, insights and thoughts that the author ascribes to the characters. In order to express the characters' perspectives on their relationships, the narrator also uses naming. In the Gospels, for instance, the names used for Jesus (e.g., Son of God, Kyrios, Son of Man) function as honorary titles. These titular names given to a character by others, are expression of their relationship with and perspective on the character. 
The article consists of five sections. Section one is the introduction. Section two is a reflection on the narrative nature (poetics) of a gospel. Section three demonstrates why Mark can be seen as a "kerygmatic story". Section four reflects on characterisation in Mark by means of the narrator's use of names for Jesus. The article concludes in section five with the finding that Mark as narrator treats Messiah as a description of Jesus' identity, but this alone does not suffice. The title Son of God is added in order to describe Jesus' identity more fully.

\section{The Synoptic Gospels: Their evolution and narrative poetics}

The term poetics comes from the Greek $\pi$ ol $\in W$ (to make). It refers to the literary theory by means of which the organisation of a discourse is investigated (see Gräbe, 1986:156). The Gospels are regarded as narratives since the elements of a narrative are present: a narrator, a story and a reader. Analysing a narrative comprises investigating the elements of author, narrator, implied reader, real reader, characters, time and space in their various relationships (see Moore, 1989:41-55). The plot (how events are structured) of a story can be simplex or complex. Characterisation is essential to the plot, which is determined by the relationships between the characters. Intrigue is created by elements of surprise and tension. The point of view of the narrator is the way in which the story is presented. The point of view refers to the perspective of the narrator, in other words how the world is seen and presented to the reader. It also refers to the ideological perspective which determines how the narrator evaluates the world (see Sternberg, 1985:129). Because the Gospels are religious texts, the narrator's ideological perspective is, simultaneously, the theological perspective. In the analysis of narrative strategies, the narrator's ideology/theology is revealed (see Van Aarde, 1988:236-238). In other words the underlying "idea" can be identified.

The Gospels are narratives of a simplex nature: the perspective of the author, the narrator and the main character (protagonist) are the same (see Petersen, 1978:97-121). All events are presented from one perspective, that is the perspective of Jesus. However, the nature of this dominant ideological/theological perspective differs in the various Gospels.

Once written, a story has a life of its own: its own world, design and inner harmony. The Gospels are such stories (see Vorster, 1986:42-62). They are not pure fiction, however, but are the literary products of a narrator who is, at the same time, also a redactor (see Van Aarde, 1986:62-75). The work of the redactor is to gather material from traditions and rework them in a creative way. The final product articulates the theology and 
ideology of the narrator. A narrative interpretation of the text is not so much interested in the historical author or reader, but rather in the narratological techniques the author uses (cf. Moore, 1989:38). These techniques reveal the ideological motives behind the redactional work. Phraseology (or diction) refers to the choices made when editing the source material: what is included, omitted, expanded or reduced? Sometimes the author is not completely successful in harmonising the source material with the story and then the source becomes more visible to the analyst.

A story mirrors its world and so do the Gospels. The socio-political, economical, religious and cultural context in which the story was born, is revealed. The Gospels, as redaction of earlier traditions, reveal two social realities: the world of the earlier period of the transmission of the traditions, and the world of the later period when the story was written. The traditional material was selected and used in such a way that it could contribute to the process of meaning making and interpreting the social world of the author. The following are examples of elements from the Jesus tradition used by the evangelists in this way (see Van Aarde, 1991:101-128):

- Jesus' conflict with scribes and village leaders concerning the interpretation of the Torah sheds light on the rift in the post-Easter community of Jesus followers between the synagogue and the Jesus factions which led to the reorganisation of Pharisaism at Jabneh and other centres in Galilee and Syria.

- Jesus' claim that God is his Father is used to ascribe authority to Jesus and those who proclaim the kerygma about him, and evolves to the canonisation of the New Testament documents in early Christianity.

The Gospels were written from the perspective of hindsight (post-Easter) and are left open-ended. The story does not end with the end of Jesus' earthly life, but is only completed when the Jesus movements take it further. The story is aimed at convincing the reader to do exactly that. Narrative strategies are employed to draw the reader into the story in order to experience and become actively involved with the story. The author's intention is to change the social world. With this in mind, the narrative strategy is chosen.

Not only the text itself, but also the strategy the author uses to communicate, are products of the social environment (see Van Aarde, [1992]:14-18). In order to investigate the poetics (strategy) of a text, both the macrosocial context (extratextual, e.g. the first-century Mediterranean environment) and the microsocial context (intratextual, e.g. how the 
first-century Mediterranean environment is mirrored in the narrative world of the text) should be taken into account. The text is not equal to the reality of its surrounding world, but presents a perspective on that reality. The Gospel narratives each have their own unique theological/ ideological approach.

The Gospels are related as third-person narratives. The choice of this narrative strategy means that the narrator's position is outside the story (not as in a first-person narrative where the narrator is a character in the story). Therefore the author refers to the characters by giving them names: proper names (e.g., Peter), personal pronouns (e.g., she or he), and titles (e.g., Son of God) (cf. Petersen, 1978:112; Moore, 1989:27). A third-person narrator chooses the strategy of either an omniscient point of view, or a limited point of view, creating respectively distance or proximity between characters and author/reader (see Uspenski, 1973: 83). An investigation of this strategy can elucidate whether a character acts according to the ideological/theological perspective of the narrator (and becomes a bearer of it - Uspenski, 1973:97-98), or in opposition to it.

The psychological narrative situation is about the narrator's choice whether to describe the character internally (describing the characters' innermost thoughts, feelings and observations) or externally (the acts of the character are described in an impersonal manner).

The narrator also makes a choice concerning time: either story time (the chronological, linear reconstruction of events) or plotted time (cf. Brink, 1987:92; Petersen, 1978:47-48). The latter pertains to how the narrator manipulates time in order to emphasise certain events. The study of how time is employed as a narrative strategy will reveal the narrator's ideological/theological focus. There is a similar distinction concerning space in a narrative: whether it simply indicates location, or whether the spaces in the story have some functional significance (see Van Eck, 1995:137). The latter being the case, an analysis of space in the story will also reveal the narrator's ideological/theological perspective. The choice of narrative strategy will emphasise a tendency toward either consensus or opposition/conflict in the story.

An analysis of phraseology reveals how characters are portrayed and gives clues as to the ideological perspective(s) of the narrator (cf. Vorster, 1987:57-76). There are two types of characters (see Kenney, 1966:29-30). The simplex character presents only one ideological perspective throughout the story. The complex character, on the other hand, often acts in an unexpected way, is at times hesitant, uncertain and full of doubts. This creates tension. Some characters merely play a 
"decorative" role and are not important to the development of the plot. They can fulfil the function of, for instance, creating the norms for judging the main character. The ideological perspective of the narrator is revealed in the way in which the characters relate to one another. The ideological perspective of the narrator can be seen in the emotions, observations, insights and thoughts that the author ascribes to the characters.

Naming can be used by the narrator to express the characters' perspectives on their relationships (see Uspenski, 1973:22, 25-27). In the Gospels, for instance, the names used for Jesus (e.g., Son of God, Kyrios, Son of Man) function as Würdeprädikationen. These titular names given to a character by others, are expression of their relationship with and perspective on the character (see Van Aarde, 1994:44-45).

\section{Mark's narrative point of view}

Central to Mark's Gospel is the death of Jesus on the cross. This Jesus is also the one who is to come. The author of the Gospel of Mark expects the final coming of Jesus (Mark 13:24-27). However, the cross is more important to Mark than the parousia and this emphasis shapes his ideas about Jesus and salvation (Kingsbury, 1981:28). Ernest Best (1983:66) refers as follows to Mark's emphasis on the death of Jesus:

The death of Jesus broods over the entire Gospel. It first becomes explicit at 3.6 where, after a series of controversies between Jesus and the Jewish leaders, the Pharisees and the Herodians take counsel together how they may eliminate him. It was however already probably implicit in the very first incident in which Jesus is involved, his baptism. Whether we take the words, 'You are my beloved Son; with you I am well pleased', as based on the words of the suffering servant in Isaiah or on the words of Abraham to Isaac when he took him away to sacrifice him the thought of death is present. In any case, the Christian community for whom Mark was writing knew that Jesus' life ended with his execution at Jerusalem. The first readers of the Gospel before they heard it knew its content, not only the individual paragraphs but also its end, the death and resurrection of Jesus.

We have seen that Mark was one of the first authors to compile a gospel out of a large body of material. This material included sayings of Jesus, as well as narrative commentary on his sayings and deeds (cf. Vorster, 1995:269-288).

That Mark's Gospel is a narrative, cannot be doubted ... The story he created is Mark's image and the narrative world is his narrative world. He selected and arranged his material in terms of order and 
space and it is he who decided on what each character will do or say and when. Even if Mark closely followed tradition and 'historical events', it was still he who created the image ... Jesus ... (Vorster, 1995:272).

The pre-Marcan stories were transmitted orally throughout the Jesus communities. Some of them were clustered together in the written evidence of the early $Q$ tradition. Examples of such larger sections are the debates (Mark 2:1-3:6), the parables (Mark 4), the miracle stories (Mark 4:35-6:52) and the teaching of Jesus (Mark 14-15) (Kingsbury, 1981:28).

Since the pioneering work of William Wrede (1971; 1904:169-177) Marcan scholars have become convinced that, in reworking the material, the author of the Gospel of Mark transformed it into a work of literature and into a work of theology. In the first part of the Marcan story (1:14-8:26) the narrator tells of Jesus gathering disciples (see Tannehill, 1995:169196; Best, 1983:83-92), teaching and preaching, healing and exorcising demons (see Kingsbury, 1981:29). In the second part (8:27-16:8) the author portrays Jesus on a journey from Galilee to Jerusalem (see Malbon, 1995:253-268; cf. Van Eck, 1995:11-70). There he undergoes terrible suffering which ends in his death. But Jesus does not remain dead - he is raised from death and lives again.

A diachronic investigation of Galilee and Jerusalem in the Gospel of Mark focuses attention on the journeys of the Marcan Jesus and on the various ways in which these journeys are anticipated. A close chronological reading brings out narrative patterns of foreshadowing or echoing - to suggest both a visual and an auditory metaphor.

Jesus' initial journey from Nazareth of Galilee to Judea, near Jerusalem (1:9), foreshadows Jesus' final journey to Judea, to Jerusalem. In the beginning Jesus journeys to Judea to be baptised by John into a ministry that leads, in the end, to a journey to Jerusalem to be crucified. But Jesus' initial return to Galilee from the wilderness in Judea $(1: 14)$ also foreshadows Jesus' final return to Galilee 'as he told you' from the tomb in Judea (16:7). The ministry of the Marcan Jesus opens with Jesus' return to Galilee from Judea; the Marcan closing anticipates a like return (Malbon, 1995:258).

The author of Mark places the story of Jesus against the background of the Old Testament story of God and God's people. What happens to Jesus is interpreted by Mark as a fulfilment of Old Testament prophecy (see Vorster, 1981:62-72; Sanders \& Davies, 1996:270-271). As "theologian", Mark interprets Jesus' life as the fulfilment of Old Testament promises and, therefore, the focal point of God's interaction with human beings. The figures of both John the Baptist and Jesus of Nazareth are a 
clear indication that the eschatological time has dawned. This is the era that begins with John and will end with the final triumphant coming of Jesus. The eschatological time includes the ministries of John, Jesus and the early followers of Jesus (before and after Easter). Yet, for the author of Mark, the emphasis is clearly on the ministry of Jesus. This ministry is narrated from Mark's post-Easter context in which Christianity redefined its identity in relation to formative Judaism (see Mack, 1988:355-356; McKay, 1998:106).

In order to understand Mark's portrayal of Jesus as the "crucified Christ" (Tatum, 1999:59), several related themes should be taken into account. Mark does not often use the expression Son of God to refer to Jesus, but when he does, a specific function is intended. For instance, Mark's very first description of Jesus is that he is Son of God (Mark 1:1). (Some scholars, however, see this title as "additional", since it "is missing in several important MSS and in quotations cited in a number of early Christian authors" [Schmidt, 1990:42]). God calls Jesus Son of God at his baptism and transfiguration (Mark $1: 11 ; 9: 7$ ) and so do the unclean spirits (Mark 3:11). When Jesus is dying the Roman centurion who is present at the cross makes the statement: "Truly this man was God's Son" (Mark 15:39). "For the cross, Jesus made his way to Jerusalem. By the cross, he is revealed to be Son of God (Tatum, 1999:59). This "high Christology" is found in the story of Mark from the beginning to the end. Mark 1:21-45 develops the theme of Jesus the Son of God (Mark 1:1, 11; cf. "the Holy One of God" - Mark 1:24). Here Jesus exemplifies authority in word and deed (Mark 1:21-22, 27, 29-31, 41). Osborne (1994:162163) puts is as follows:

This new authority 'astounds' (v. 22) and 'overwhelms' (v. 27) the people, who see the hand of God in Jesus but cannot understand the true meaning of his actions ... This authority is especially evident in Jesus' teaching. Even his deeds are called 'a new teaching with authority' (v. 27), and Jesus' priorities clearly center on preaching the kingdom message (v. 38-39) ... Yet Jesus' miracles at the same time exemplify his authority and are a focus of his messianic activity.

The theme of the "messianic secret" pervades Mark (Tatum, 1999:59). Throughout the Gospel of Mark Jesus is portrayed as trying to keep his identity and task a secret.

Jesus orders demons, witnesses to his healings, and even his own disciples not to make him known $(1: 34 ; 3: 12 ; 5: 43 ; 7: 24,36$; 8:36; $9: 9,30)$. In Mark, the evangelist appears to be using the secrecy motif to show that Jesus has de-emphasized the more spectacular aspects of his ministry in favor of his vocation as the suffering 'Son 
of Man' (8:31; 9:31; 10:32-34) and suffering 'Son of God' (15:39)

(Tatum, 1999:59 - italics YD).

Mark's presentation of the story of Jesus is from a specific point of view and with a specific intention. The direction of his thought can be seen from early on in his narrative (cf. Matera, 1995:289-306). Throughout the story he gives clues as to what is going to happen to Jesus. One such clue is the fate of John the Baptist (see Matera, 1995:393-294). Since his role is linked to that of Jesus, what happens to him gives the reader an indication of where Jesus is heading (cf. Mark 14:43-46). Another clue is Jesus' interaction with the Galilean and Judean élite. Jesus teaches "as one who had authority, and not as the scribes" (Mark 1:22). The controversy stories give evidence of conflict between Jesus and the élite (see Dewey, 1995:141-152). These stories concern cultic regulations and the controversies are settled by appeals to "Christological" arguments (cf. Kuhn, 1971:82-83). According to Jerome Neyrey (1998:675), "Mark's narrative consists of a constant testing of Jesus' claim to be a reforming prophet or an authorised son of God and a constant refusal to acknowledge the claim". According to Dewey (1995:149), the controversy stories "serve the needs of the [Judean] community against Jewish Christians who accept the full power of the earthly Son of Man". Mark portrays the élite plotting against Jesus (Mark 3:6) and Jesus alluding to his fate (Mark 2:20). When Jesus chooses his disciples, Judas is directly pointed out as "the one who also betrayed him" (Mark 3:19) (see Kingsbury, 1981:30).

Jesus comes into conflict not only with "the enemies" such as the élite and the Judean crowd (Mark 4:1-2), but also with those who are supposed to be his "friends", his family (Mark 3:20-21, 31-35) and fellow villagers (Mark 6:1-5) (see Kingsbury, 1981:31). Alienation is reported throughout the story and leads to Jesus' suffering and eventual death on the cross (Mark 15:25-41). The passion of Jesus is the focal point of Mark's narrative. Almost everything in the story (previews, e.g. the passion predictions, and flashbacks, e.g. the resurrection) points to the cross. In the scene of Jesus' resurrection he is still called "the one from Nazareth" (Mark 16:6), indicating that he remains the crucified one even though he has risen.

The way in which Mark tells his kerygmatic story indicates that he sees the cross as the key to understanding the work and person of Jesus. This has narrative implications (Kingsbury, 1981:32). It is to be expected that the various narrative lines will come together at this point (see Via, 1975:128-130). According to Kingsbury (1981:32) at least three such narrative lines can be indicated: 
- the line of the story as revealed by the summary passages Mark selects;

- the secret of Jesus' identity as the royal Son of God;

- the incomprehension of the disciples to understand the mission of Jesus before his death and resurrection.

Via (1975:128-130) sees the line of the incomprehension of the disciples intersecting with the line of the rejection of Jesus by his opponents at the cross. However, Tannehill (1995:188) emphasises that

... there is a sense in which the disciples' story is not over. There are features of the story which hold the future open ... So the Gospel holds open the possibility that those who deserted Jesus will again become his followers, reinstating the relationship established by Jesus' call.

\section{Characterisation and naming}

In the prologue (Mark 1:1-13 [15]) Jesus is introduced as the main character and John the Baptist as his predecessor (Mark 1:2, 7). The story of John the Baptist is told (1:2-8) to anticipate the tragedy of Jesus' life-story. John predicts that someone will come who is mightier than he (Mark 1:7) and then Jesus comes onto the scene (Mark 1:9-13) (Kingsbury, 1981:33). Jesus is empowered by the Holy Spirit (Mark 1:10) and is declared to be God's beloved Son (Mark 1:11) by a voice from heaven. Mark quotes from the Hebrew Scriptures: Genesis 22:2, Psalm 2:7, and Isaiah 42:1 (cf. Sanders \& Davies, 1996:270-271). By applying these words to Jesus he depicts Jesus as the one chosen and sent by God to inaugurate the eschatological kingdom for Israel. The reference to Psalm 2:7 indicates that Jesus is also the king of Judah from the line of David. Mark's picture of Jesus is that he is the Davidic Messiah expected by Israel. Sanders and Davies (1996:271) formulate it as follows:

In Mark, Jesus is the Messiah, the Son of David, understood to be predicted in Scriptural passages like Ps. 118.25f. (Mark $11.9 \mathrm{f}$. and $10.47 \mathrm{f}$.) ... In the Passion narrative, 'the king of the Jews' (Mark $15.2,9,12,18,26$; cf. 15.32) is ... a key term in the trial before Pilate and the crucifixion.

This Messiah is, at the same time, the Son of God: "The beginning of the Gospel of Jesus Messiah, the Son of God" (Mark 1:1). The term messiah is a derivative of the Hebrew ha-mashiah ("the Anointed"). The term was a later development and refers to Israel's end-time saviour. According to Cohn-Sherbock (1997:2-3), textual references in the Torah such as the 
promise to Abraham (Gen. 12:2-3), the promise to Isaac (Gen. 26:3-4) and the Jacob covenant (Gen. 28:12-14), are implicit reverse projections of a messianic expectation. This expectation becomes explicit in texts such as 2 Samuel 23:1, 3, 5 and 2 Samuel 7:8-10 where the messianic idea is connected with the Davidic dynasty. David is seen as the "anointed" (messiah) of God. God's provision and protection will become manifest in the actions of the long line of successors to the Davidic throne (see Horbury, 1998:66-67). At the same time the messianic idea began functioning as the symbol of the ideal of a unified Israel, no longer divided by the interests of the North and the South (see Amos 9:11-12). Richard Horsley (1996:19) refers as follows to this ideal:

According to the histories of the monarchy written or edited by royal scribes, the representative 'elders' of all the tribes participated in the popular acclamation or 'anointing' (messiah) of David as king over all Israel (2 Sam. 5:1-3).

The prophet Amos (see 5:16-17; 6:7; 7:17; 8:10), however, was certain that destruction and exile would occur before this ideal could be attained (see Cohn-Sherbock, 1997:4-5). The prophet Hosea (6:1-2) seemed to have had a similar thought:

Come, let us return to the Lord;

for [God] has stricken, and [God] will bind us up.

After two days [God] will revive us;

and on the third day [God] will raise us up,

that we may live before [God] (RSV).

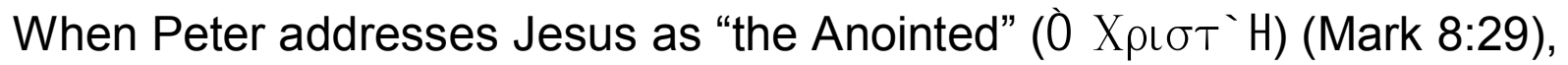
Mark lets Jesus react with the "messianic secret" formula (Mark 8:30), keeping Peter from making this confession public. In the context of the Gospel of Mark (also taken over by Matt. 16:22-23) it is clear that Peter did not see "destruction" as a necessary prerequisite for the coming of messianic redemption. The Marcan Jesus (as continued by Matt. 16:21), however, declares that the triumphant Son of Man will be raised to life after three days (Mark 8:31; 9:31; 10:33-34 - cf. Hosea 6:1-2). Mark shows that Peter (Mark 8:29-30), the Twelve (Mark 9:33) and the sons of Zebedee (James and John) (Mark 10:35-45), the "pillars" of the postEaster Jesus movement in Jerusalem (Gal. 2:9), did not understand what God intended with the messianic ideal. Peter wants the "healing" without the preceding "destruction". The disciples yearn for greatness and the sons of Zebedee for royal honour. The Markan Jesus is the realisation of the prophetic word (Is. 11:1-2, 3-4, 6) about a messianic ideal of service and being present for the poor:

There shall come forth a shoot from the stump of Jesse, and a branch shall grow out of his roots. 
And the Spirit of the Lord shall rest upon him ...

He shall not judge by what his eyes see,

or decide by what his ears hear;

But with righteousness he shall judge the poor,

and decide with equity for the meek of the earth (RSV).

The messianic ideal reaches a climax in the third prediction of Jesus' suffering at the turning point of the plot in Mark's narrative. The sons of Zebedee (John and James) are admonished by Jesus (Mark 10:42-45) not to desire to be like those who rule over the nations (о $\delta$ око $\ddot{y} v t \in$ l

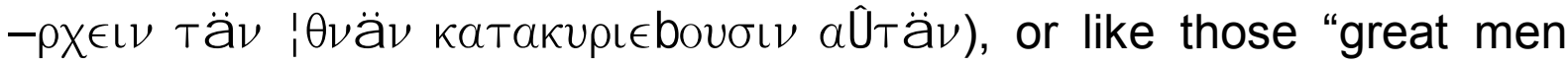

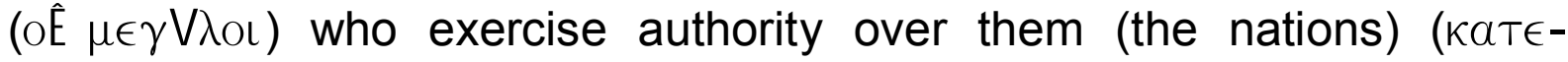

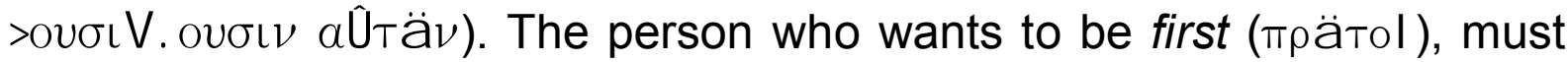
be everyone's slave ( $\delta \circ \mathrm{y} \lambda \mathrm{ol})$. The Son of Man (i.e., the triumphant

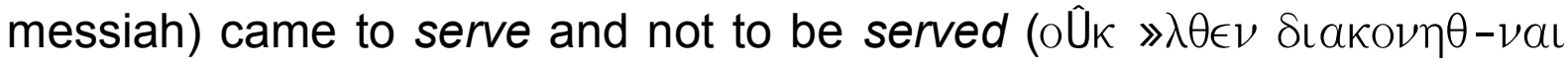
ï $\lambda \lambda$ è Sıakov Bartimaeus of Jericho, and not the "pillars" of the Jesus faction in Jerusalem, who had insight into the role of the serving and healing Son of David (Messiah). Mark narrates that Bartimaeus, when he heard that Jesus who was moving through the streets of Jericho on his way to Jerusalem, shouted: "Son of David [Messiah], have mercy on me" $\left.(\Upsilon \bullet \Delta a u \backslash \delta, \mathbb{R} X\rceil \sigma^{`} \nu \mu \epsilon\right)$. In the following pericope (Mark 11:1-11) Mark tells the story (by adapting Psalm 118:25-26) of how the followers of Jesus in general and not the Twelve in particular, were the ones who honoured Jesus when he entered Jerusalem on a donkey. The followers

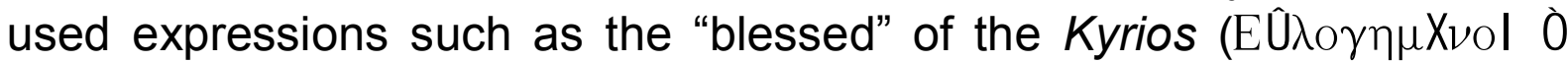

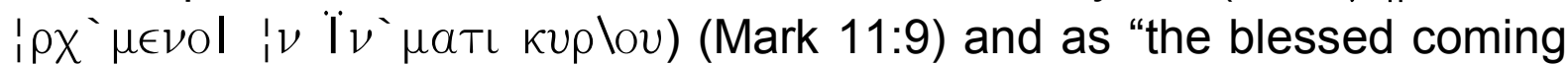

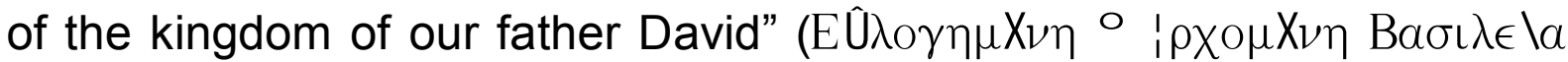

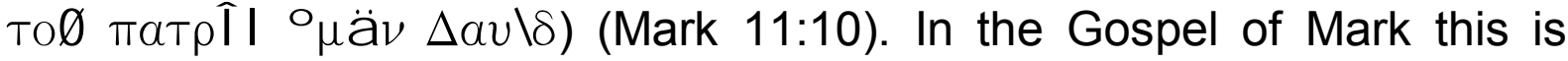
followed by the story of Jesus cleansing the Jerusalem temple. Here, too, the messianic ideal of God's righteousness and justice for those who are deprived of provision and protection by the patrons of the people, can be seen (see Ps. 72:112-114). In the Gospel of Mark (11:17) Jesus cites Jeremiah (7:11), where the Second Temple ideology is compared with a "den of bandits" ( $\sigma \pi Z \backslash$ alov $\lambda / \approx \sigma \%)$. According to the messianic ideal of a united Israel, the temple in Jerusalem is "God's house", and this house "will be called a place of prayer for all nations" (" o $\Delta \mathrm{ol}$ l $\mu \mathrm{ov}$

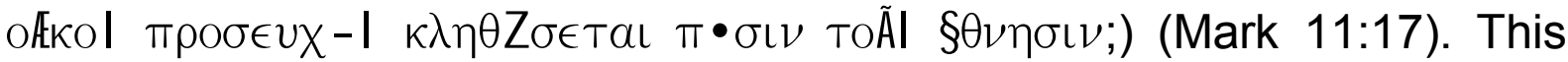
ideal of unity can also be found in, among others, Isaiah 26:1-4; Micah 2:12; 4:2-4; Zephaniah 3:19-20; Jeremiah 23:5-6; 31:31-33; 33:14-16; Ezekiel 37:24:25 (see Cohn-Sherbock, 1997:8-16). 
Jesus' teaching in the temple in Mark 12:35-37 provides a key to understanding why the later faction of the Jesus movement in Jerusalem failed to grasp the meaning of Jesus' messianic role. It also shows that Mark considers the title Messiah not to be an adequate symbol in itself with which to evaluate Jesus' work. In order to express adequately both the defeat (crucifixion) and the victory over defeat (resurrection), Mark adds the title Son of God, taken from the Graeco-Hellenistic background, to that of Messiah of Israel. Matthew concurs with Mark and expands the confession of Peter (Matthew 16:16) that Jesus is "the Christ, the Son of

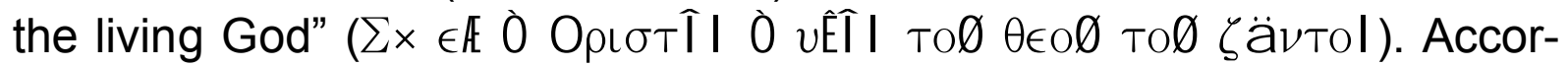
ding to Mark 8:29, Peter simply calls Jesus "Messiah": $\Sigma \downarrow \in \Delta^{\prime \prime}$ Opı $\sigma \tau \mathbb{F}$. In Mark 15:37 the dying moment of Jesus is described metaphorically as the triumphant call of a herout: "Jesus called in a loud voice"

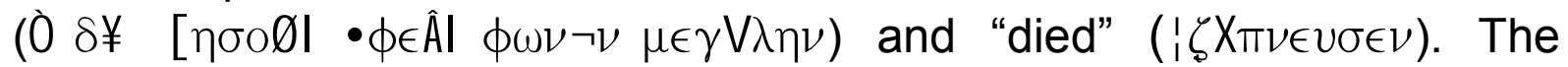
Roman centurion (Mark 15:39) reacted to this with an extended acknowledgement of the "truth" about Jesus, namely that he was truly

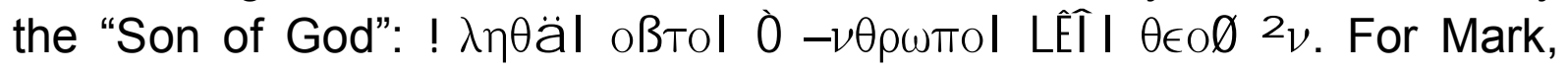
Jesus' claim to authority lies not only within the Würdeprädikation "Messiah of Israel", but more specifically in the value judgement that Jesus as Messiah is also the suffering and triumphant Son of God.

An emphasis only on the messiahship of Jesus could lead to the desire to be "high officials", without taking into account what it really means to follow Jesus: suffering, dying and being triumphant servants. The latter goes together with Jesus being "Messiah" and "Son of God". Mark 12:3537 recounts the controversy between Jesus and the Jerusalem scribes. They want to understand "Son of David" only in the sense of might and power. According to Mark, Jesus cites from Psalm 110:1 where "messiah" is understood as a subordinate to the Kyrios (cf. CohnSherbock, 1997:17): "The Lord says to my lord: 'Sit at my right hand ..." (Ps. 110:1 - RSV). According to the Marcan Jesus, it is David, as an

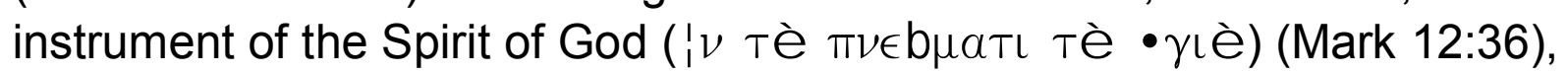
who is speaking here. Jesus then asks: if David calls the addressee Kyrios, how can David be the son of the Kyrios (God) (Mark 12:37). The meaning is clear: the "truth" about the authority of Jesus ( $\ \triangleright v \sigma \backslash \alpha)$ is that he is more than just "son of David" (= "messiah"). As Messiah he does not have authority, because the "messiah" is subordinate to the Kyrios. Jesus as Son of God has authority. His authority is confirmed by his victory over suffering and death (see also Rom. 1:3-4).

Jesus' words and deeds are presented in a way which affirms that he is indeed the royal Son of God and Messiah enabled by the Spirit of God to fulfil his function. He speaks and acts with divine authority ( $\$ \ngtr v \sigma \backslash \alpha)$, he declares that the time of God's kingdom has arrived (Mark 1:14-15), he 
calls his followers (Mark 1:16-20), does exorcisms and performs healings in order to restore the broken lives of people. Mark, however, keeps this identity of Jesus as Son of God a secret from the people, though of course God and the demons know who Jesus is (see Sanders \& Davies, 1996:272). As the story unfolds only certain aspects of the secret are revealed (Kingsbury, 1981:34). From time to time Mark has people asking questions as to Jesus' identity. Characters in the story answer these questions with their ideas of who he is. But the answers are all incorrect. This contrasts with assertions about Jesus that are only partially correct. In this way the secret of Jesus' identity as Son of God remains intact. Only at the end of the story, at Jesus' death and resurrection, is the secret revealed. By telling the story in this way the author indicates that Jesus' identity as the royal Son of God is crucial to his destiny. As the obedient Son of God he is willing to go the way of the cross (see Mark 14:35-36) (Kingsbury, 1981:34).

[T] he phrase 'Son of God' indicates his importance, but by picturing him as a truly obedient Israel, not as the Second Person of the Trinity. The synoptic Gospels did not formulate questions about Jesus' nature in the terms which were exercised by later generations of Christians and hence had no need to use 'Son' in the sense found in the Creeds (Sanders \& Davies, 1996:272).

\section{Conclusion}

When Mark tells the story of Jesus, the history of Israel is reflected in his story. However, in Mark Jesus' teaching is a new teaching with authority. The more spectacular aspects of his deeds are de-emphasised in favour of his vocation as the suffering Son of Man and the suffering Son of God: the Messiah is at the same time the Son of God. Therefore the disciples should not want to be like "first men" or "great men" who enjoy having authority over others. Mark distinguishes among the twelve disciples who want powerful positions and the other followers (disciples) of Jesus. According to Mark it is not the Twelve but some of the other followers who praise Jesus with the title of the Blessed One who comes in the name of the Kyrios. Messiah is the title the disciples give to Jesus, but the "narrated Jesus" subordinates the title Messiah to the title Kyrios. Mark as narrator treats Messiah as a description of Jesus' identity, but it alone does not suffice: the title Son of God is added in order to describe Jesus' identity more fully.

\section{Bibliography}

BEST, E. 1983. Mark: The Gospel as story. Edinburgh : Clark. (Studies of the New Testament and its world.) 
BRINK, A.P. 1987. Vertelkunde: 'n Inleiding tot die lees van verhalende tekste. Pretoria : Academica.

COHN-SHERBOCK, D. 1997. The Jewish Messiah. Edinburgh : Clark.

DEWEY, J. 1995 [1973]. The literary structure of the controversy stories in Mark 2:13:6. (In Telford, W.R., ed. The interpretation of Mark. Second edition. Edinburgh : Clark. p. 141-152.)

GRÄBE, I. 1986. Narratologiese ondersoek en eksegese van die boodskap van die evangelies. Hervormde Teologiese Studies, 42:151-168.

HORBURY, W. 1998. Jewish messianism and the cult of Christ. London : SCM.

HORSLEY, R.A. 1996. Archeology, history, and society in Galilee: The social context of Jesus and the rabbis. Valley Forge, PA : Trinity Press International.

KENNEY, W. 1966. How to analyze fiction. New York: Monarch.

KINGSBURY, J.D. 1981. Jesus Christ in Matthew, Mark, and Luke. Phildelphia, PA : Fortress. (Proclamation Commentaries.)

KUHN, H-W. 1971. Ältere Sammlungen im Markusevangelium. Göttingen : Vandenhoeck \& Ruprecht.

MACK, B.L. 1988. A myth of innocence: Mark and Christian origins. Philadelphia, PA : Fortress.

MALBON, E.S. 1995 [1982]. Galilee and Jerusalem: History and literature in Marcan interpretation. (In Telford, W.R., ed. The interpretation of Mark. Second edition. Edinburgh : Clark. p. 253-268.)

MATERA, F.J. 1995 [1988]. The prologue as the interpretative key to Mark's Gospel. (In Telford, W.R., ed. The interpretation of Mark. Second edition. Edinburgh : Clark. p. 289-306.)

MCKAY, H. 1998. Ancient synagogues: The continuing dialectic between two major views. Currents in Research: Biblical Studies, 6:103-142.

MOORE, S.D. 1989. Literary criticism and the Gospels: The theoretical challenge. New Haven, MA : Yale University Press.

NEYREY, J.H. 1998. Questions, chreiai, and challenges to honor: The interface of rhetoric and culture in Mark's Gospel. Catholic Biblical Quarterly, 60(4):657-681.

OSBORNE, G.R. 1994. Structure and Christology in Mark 1:21-45. (In Green, J.B. \& Turner, M., eds. Jesus of Nazareth: Lord and Christ. Essays on the historical Jesus in New Testament Christology. Grand Rapids, MI : Eerdmans. p. 147163.)

PETERSEN, N.R. 1978. "Point of view" in Mark's narrative. Semeia, 12:97-121.

SANDERS, E.P. \& DAVIES M. 1996 [1989]. Studying the synoptic Gospels. Fifth impression. London : SCM.

SCHMIDT, D.D. 1990. The Gospel of Mark, with introduction, notes and original text featuring the New Scholars Version Translation. Sanoma, CA : Polebridge. (The Scholars Bible.)

STERNBERG, M. 1985. The poetics of Biblical narrative: Ideological literature and the drama of reading. Bloomington, IN : Indiana University Press.

TANNEHILL, R.C. 1995 [1977]. The disciples in Mark: The function of a narrative Role. (In Telford, W.R., ed. The interpretation of Mark, Second edition. Edinburgh : Clark. p. 169-196.)

TATUM, W.B. 1999. In quest of Jesus. Revised and enlarged edition. Nashville, TN : Abingdon.

USPENSKI, B. 1973. A poetics of composition: The structure of the artistic text and typology of a compositional form. Tr. by V. Zavarin \& S. Wittig. Berkeley, CA : University of California Press. 
VAN AARDE, A.G. 1986. Plot as mediated through point of view: Matt. 22:1-14 - a case study. (In Petzer, J.H. \& Hartin, P.J., eds. A South African perspective on the New Testament: Essays by South African scholars presented to Bruce Manning Metzger during his visit to South Africa in 1985. Leiden : Brill. p. 6275.)

VAN AARDE, A.G. 1988. Narrative point of view: An ideological reading of Luke 12:35-48. Neotestamentica, 22:235-252.

VAN AARDE, A.G. 1991. Narrative criticism applied to John 4:43-54. (In Hartin, P.J. \& Petzer, J.H., eds. Text and interpretation: New approaches in the criticism of the New Testament. Leiden : Brill. p. 101-128.) (New Testament Tools and Studies 15.)

VAN AARDE, A.G. [1992]. Eksegetiese metodologie: Narratologie. Unpublished study guide. Department of New Testament Studies, Faculty of Theology, University of Pretoria.

VAN AARDE, A.G. 1994. God-with-us: The dominant perspective in Matthew's story, and other essays. Pretoria : University of Pretoria. (HTS Suppl 5.)

VAN ECK, E. 1995. Galilee and Jerusalem in Mark's story of Jesus: A narratological and social scientific reading. Pretoria : University of Pretoria. (HTS Suppl.)

VIA, D.O. 1975. Kerygma and comedy in the New Testament: A structuralist approach to hermeneutics. Philadelphia, PA : Fortress.

VORSTER, W.S. 1981. The function of the use of the OT in Mark. Neotestamentica, 14:62-72.

VORSTER, W.S. 1986. The New Testament and narratology. Journal of Literary Studies/Tydskrif vir Literatuurwetenskap, 2:42-62.

VORSTER, W.S. 1987. Characterisation of Peter in the Gospel of Mark. Neotestamentica, 21:57-76.

VORSTER, W.S. 1995 [1987]. Literary reflections on Mark 13:5-37: A narrated speech of Jesus. (In Telford, W.R., ed. The interpretation of Mark. Second edition. Edinburgh : Clark. p. 269-288.)

WREDE, W. 1971 [1901]. The messianic secret. Tr. by J.C.G. Greig. London : James Clarke.

WREDE, W. 1904. Zur Messiaserkenntnis der Dämonen bei Markus. Zeitschrift für Neutestametliche Wissenschaft, 5:169-177.

\section{Kernbegrippe:}

Messias; ondergeskik aan die titel Kyrios

name van Jesus in Markusevangelie

narratiewe kritiek

Seun van God as eretitel

\section{Key concepts:}

Messiah; subordinate to titel Kyrios

names of Jesus in Gospel of Mark

narrative criticism

Son of God as honorary title 